\title{
Coptidis rhizoma extract protects against cytokine-induced death of pancreatic $\beta$-cells through suppression of NF-KB activation
}

\author{
Eun-Kyung Kim ${ }^{1 *}$, Kang-Beom Kwon ${ }^{2 *}$, \\ Mi-Jeong Han ${ }^{1}$, Mi-Young Song ${ }^{1}$, \\ Ji-Hyun Lee ${ }^{1}, \mathrm{Na} \mathrm{Lv}{ }^{1}$, Sun-O Ka ${ }^{1}$, \\ Seung-Ryong Yeom ${ }^{3}$, Young-Dal Kwon ${ }^{3}$, \\ Do-Gon Ryu ${ }^{2}$, Kang-San Kim ${ }^{4}$, \\ Jin-Woo Park ${ }^{1}$, Raekil Park ${ }^{5}$, and \\ Byung-Hyun Park, \\ ${ }^{1}$ Department of Biochemistry \\ Medical School and Institute for Medical Sciences \\ Chonbuk National University \\ Jeonju, 561-756, Korea \\ ${ }^{2}$ Department of Physiology \\ ${ }^{3}$ Rehabilitation Medicine \\ ${ }^{4}$ Internal Medicine \\ School of Oriental Medicine \\ ${ }^{5}$ Vestibulocochlear System Research Center \\ Wonkwang University \\ Iksan 570-749, Korea \\ ${ }^{6}$ Corresponding author: Tel, 82-63-270-3139; \\ Fax, 82-63-274-9833; E-mail, bhpark@chonbuk.ac.kr \\ *These authors contributed equally to this work.
}

Accepted 22 January 2007

Abbreviations: CRE, Coptidis rhizoma extract; GSIS, glucosestimulated insulin secretion; NO, nitric oxide

\begin{abstract}
We demonstrated previously that Coptidis rhizoma extract (CRE) prevented S-nitroso-N-acetylpenicillamine-induced apoptotic cell death via the inhibition of mitochondrial membrane potential dis ruption and cytochrome $c$ release in RINm5F (RIN) rat insulinoma cells. In this study, the preventive effects of CRE against cytokine-induced $\beta$-cell death was assessed. Cytokines generated by immune cells infiltrating pancreatic islets are crucial mediators of $\beta$-cell destruction in insulin-dependent diabetes mellitus. The treatment of RIN cells with IL-1 $\beta$ and IFN $-\gamma$ resulted in a reduction of cell viability. CRE completely protected IL- $1 \beta$ and IFN- $\gamma$-mediated cell death in a concentration-dependent manner. Incu bation with CRE induced a significant suppression of
\end{abstract}

IL-1 $\beta$ and IFN- $\gamma$-induced nitric oxide (NO) production, a finding which correlated well with reduced levels of the iNOS mRNA and protein. The molecular mechanism by which CRE inhibited iNOS gene expression appeared to involve the inhibition of NF-KB activation. The IL-1 $\beta$ and IFN- $\gamma$-stimulated RIN cells showed increases in NF- $\mathrm{KB}$ binding activity and $\mathrm{p} 65$ subunit levels in nucleus, and $I_{\kappa} B \alpha$ degradation in cytosol compared to unstimulated cells. Furthermore, the protective effects of CRE were verified via the observation of reduced NO generation and iNOS expression, and normal insulin-secretion responses to glucose in IL-1 $\beta$ and IFN- $\gamma$-treated islets.

Keywords: cell death; Coptidis rhizoma extract; cytokines; drugs, Chinese herbal; insulin secreting cells; NF-kappa B; nitric oxide

\section{Introduction}

Type 1 diabetes mellitus is an autoimmune disease which induces a selective destruction of the insulinproducing $\beta$-cells of the Langerhans islets (Nossal et al., 1992). A great deal of evidence supports the crucial role of infiltrating immune cells in and around the pancreatic islets at early stages of pathogenesis (Kanazawa et al., 1984; Jorns et al., 2005). In their activated state, T-lymphocytes and macrophages, which are primary cellular components of islet insulitis, secrete high levels of IL-1 $\beta$ and IFN- $\gamma$, respectively. IL-1 $\beta$ alone, or in combination with TNF- $\alpha$ or IFN- $\gamma$, induces an excess production of nitric oxide (NO) by the iNOS in the pancreatic islets (Cetkovic-Cvrlje and Eizirik, 1994; Corbett and McDaniel, 1995; Heitmeier et al., 1997; Kwon et al., 2003a). Nitric oxide is a short-lived and highly reactive radical, which inhibits the Krebs-cycle enzyme aconitase and electron transport chain complexes I and II, resulting in reduced glucose oxidation rates, ATP generation, and insulin production (Welsh et al., 1991; Corbett et al., 1992; Cunningham and Green, 1994). In fact, iNOS inhibitors, such as $N^{\mathrm{w}}$-nitro-Larginine methylester (L-NAME) and aminoguanidine, attenuate cytokine-induced $\beta$-cell dysfunction and islet degeneration (Southern et al., 1990; Welsh et al., 1991; Eizirik et al., 1996).

The transcriptional NF- $\mathrm{B}$ has been implicated as 
a key IL-1 $\beta$ signaling mediator and has also been suggested as a regulator of the transcription of the iNOS gene (Eizirik et al., 1996; Mandrup-Poulsen, 1996). NF- $\kappa B$ is initially located within the cytoplasm as an inactive form complexed with $\mathrm{I}_{\kappa} \mathrm{B}$, an inhibitory factor of NF- $\kappa$ B. A variety of inducers cause the dissociation of this complex, presumably via the phosphorylation of $I_{\kappa} B$, permitting $N F-\kappa B$ to be released from the complex. NF- $\mathrm{KB}$ is then translocated to the nucleus, where it interacts with its DNA recognition sites to mediate gene transcription (Baeuerle and Henkel, 1994; Baldwin, 1996; May and Ghosh, 1998).

Coptidis rhizoma is a rhizome of Coptis chinensis Franch, and a member of the Ranunculaceae family. It has been employed in Chinese medicine for the treatment of diabetes mellitus. A great deal of evidence suggests that it may also prove effective against inflammation (lizuka et al., 2000a), cancer cell proliferation (lizuka et al., 2000b, 2002), and the induction of novel growth-related genes, most notably $\mathrm{rcl}$ (Chan et al., 2002). We recently reported that the pretreatment of RIN cells with Coptidis rhizoma extract (CRE) prevented S-nitroso-N-acetylpenicillamine-induced apoptotic cell death (Kwon et al., 2005). In the present study, we have attempted to determine the feasibility of Coptidis rhizoma as a means for the prevention of IL-1 $\beta$ and IFN- $\gamma$-induced $\beta$-cell damage. CRE inhibited IL-1 $\beta$ and IFN- $\gamma$-induced NF- $\kappa$ B activation, iNOS expression, NO formation, glucose-stimulated insulin secretion (GSIS), and viability reduction in RIN cells and islets, which may explain the beneficial anti-diabetic effects associated with Coptidis rhizoma.

\section{Materials and Methods}

\section{Cell culture}

RINm5F (RIN) cells were obtained from the American Type Culture Collection and grown at $37^{\circ} \mathrm{C}$ under a humidified, $5 \% \mathrm{CO}_{2}$ atmosphere in RPMI 1640 medium (Gibco BRL) supplemented with $10 \%$ FBS and $2 \mathrm{mM}$ glutamine, $100 \mathrm{U} / \mathrm{ml}$ of penicillin, 100 $\mu \mathrm{g} / \mathrm{ml}$ of streptomycin, and $2.5 \mu \mathrm{g} / \mathrm{ml}$ of amphotericin $\mathrm{B}$.

\section{Preparation of Coptidis rhizoma extract}

The plants were purchased by the Wonkwang Oriental Medical Hospital in Iksan, Chonbuk, South Korea, and were confirmed by Professor Ho-Joon Song. Voucher samples were preserved in the Herbarium of the Department of Physiology, at the School of Oriental Medicine, Wonkwang Univ. (Omcphy 2001-90). For extraction, $200 \mathrm{~g}$ of Coptidis rhizoma was ground and extracted with boiling water for $4 \mathrm{~h}$. After $20 \mathrm{~min}$ of centrifugation at 3,000 $\times \mathrm{g}$, the supernatant was concentrated under reduced pressure to $200 \mathrm{ml}$ and freeze-dried to $32.12 \mathrm{~g}$. The sterile extract was then stored at $-70^{\circ} \mathrm{C}$.

\section{MTT assay for cell viability}

The viability of the cultured cells was determined via assays for the reduction of MTT to formazan, as previously described (Zhang et al., 2005). In brief, after $48 \mathrm{~h}$ of incubation, cells $\left(10^{4} /\right.$ well) in 96 -well plates were washed twice with PBS. MTT (100 $\mu \mathrm{g} / 0.1 \mathrm{ml}$ of PBS) was added to each of the wells. Cells were then incubated for $1 \mathrm{~h}$ at $37^{\circ} \mathrm{C}$, and DMSO $(100 \mu \mathrm{l})$ was added in order to dissolve the formazan crystals. The absorbance was determined at $570 \mathrm{~nm}$ with a model Spectra MAX PLUS spectrophotometer (Molecular Devices, Sunnyvale, CA).

\section{5-Bromo-2-deoxyuridine (BrdU)-labeling cell proliferation assay}

A cell proliferation enzyme-linked immunosorbent assay (BrdU kit; Amersham Biosciences, Piscataway, NJ) was employed to measure the incorporation of BrdU during DNA synthesis, in accordance with the manufacturer's protocols. In brief, the cells were seeded overnight in 96-well tissue culture plates with clear, flat bottoms (Becton Dickinson, Franklin Lakes, NJ) at a density of $10^{5}$ cells per well in $100 \mu \mathrm{l}$ of medium. The cells were treated for $48 \mathrm{~h}$ at a range of concentrations. BrdU $(10 \mu \mathrm{M})$ was added to the culture medium for $2 \mathrm{~h}$, the BrdUlabeled cells were fixed, and the DNA was denatured for $30 \mathrm{~min}$ in fixative solution at room temperature. The cells were incubated for $2 \mathrm{~h}$ with peroxidase-conjugated anti-BrdU antibody at room temperature and washed three times in washing solution. The immune complex was detected via the 3,3 ',5,5'-tetramethylbenzidine substrate reaction and absorbance was determined at $405 \mathrm{~nm}$ with a Spectra MAX PLUS spectrophotometer.

\section{Nitrite measurement}

Biologically generated $\mathrm{NO}$ is oxidized rapidly to nitrite and nitrate in aqueous solutions (Moncada et al., 1991). Nitrite concentrations in the cell-free culture supernatant, therefore, were utilized as a reflection of NO production, and were measured via a colorimetric assay (Green et al., 1982). Following $48 \mathrm{~h}$ of incubation, $100 \mu \mathrm{l}$ aliquots of the culture supernatants were incubated with $100 \mu$ of a $1: 1$ mixture of $1 \%$ sulfanilamide in $30 \%$ acetic acid and $0.1 \% \mathrm{~N}$-(1-naphthyl) ethylenediamine dihydrochloride in $60 \%$ acetic acid at room temperature. After 5 
min, absorbance was determined at $540 \mathrm{~nm}$ using a Spectra MAX PLUS spectrophotometer. NO concentrations were determined from a linear standard curve obtained from serial dilutions of sodium nitrite in working medium.

\section{RNA isolation and RT-PCR for iNOS}

Total RNA was isolated from RIN cells with Trizol reagent (Life Technologies Ltd, UK). RNA was precipitated with isopropanol, dissolved in DEPCtreated distilled water, and maintained at $-80^{\circ} \mathrm{C}$ until use. One microgram of total RNA was transcribed into cDNA in a $20 \mu \mathrm{l}$ final volume of reaction buffer (10 mM Tris- $\mathrm{HCl}, \mathrm{pH} 7.4,50 \mathrm{mM} \mathrm{MgCl}, 1 \mathrm{mM}$ each dNTP) and $2.4 \mu \mathrm{M}$ oligo-d(T)16-primer, $1 \mathrm{U}$ RNase inhibitor, and $2.5 \mathrm{U}$ MulV reverse transcriptase via 10 min of incubation at $21^{\circ} \mathrm{C}$ and $15 \mathrm{~min}$ at $42^{\circ} \mathrm{C}$. The reaction was halted via $5 \mathrm{~min}$ of incubation at $99^{\circ} \mathrm{C}$. For rat iNOS PCR, aliquots of the synthesized CDNA were added to a $45 \mu \mathrm{PCR}$ mixture containing 10 $\mathrm{mM}$ Tris- $\mathrm{HCl}, 50 \mathrm{mM} \mathrm{KCl}, 1.5 \mathrm{mM} \mathrm{MgCl}_{2}, 0.2 \mathrm{mM}$ of each dNTP, $2 \cup$ Taq DNA polymerase, and $0.4 \mu \mathrm{M}$ of each PCR primer; upstream primer, 5'-CCACAATAGTACAATACTACTTGG-3', downstream primer, 5'-ACGAGGTGTTCAGCGTGCTCCACG-3'. Amplification was initiated with $3 \mathrm{~min}$ of denaturation at $94^{\circ} \mathrm{C}$ followed by 26 cycles at $94^{\circ} \mathrm{C}$ for $1 \mathrm{~min}, 60^{\circ} \mathrm{C}$ for $1 \mathrm{~min}$, and $72^{\circ} \mathrm{C}$ for $1 \mathrm{~min}$. After the last amplification cycle, the samples were incubated for 5 min at $72^{\circ} \mathrm{C}$. $\beta$-actin PCR was conducted with $2.5 \mu \mathrm{l}$ of an aliquot of synthesized cDNA using primers at a concentration of $0.15 \mu \mathrm{M}$; upstream primer, 5'-TGCCCATCTATGAGGGTTACG-3' downstream primer, TAGAAGCATTTGCGGTGCACG-3'. The obtained PCR products were analyzed on ethidium bromidestained agarose $(1.5 \%)$ gels.

\section{Real-time PCR for iNOS in islets}

Total RNA was isolated from batches of 30 islets using Trizol reagent (Life Technologies Ltd, UK). Real-time PCR was conducted using the LightCycler rapid thermal cycler system (Roche Diagnostics Ltd, UK) in accordance with the manufacturer's instructions. Specific primers for the iNOS and $\beta$-actin genes were designed using LightCycler software 4 (Roche). The primer sequences were as follows: iNOS gene upstream primer, 5'-GTTCTTTGCTTCTGTGCTAAT-3' downstream primer, 5'-GTGTTTGCCTTATACTGTTCCA-3'; $\beta$-actin gene upstream primer, 5'-GTGCTATGTTGCTCTAGACT-3' downstream primer, 5'-CACAGGATTCCATACCCAAG-3'. The real-time PCR contained, in a final volume of $20 \mu \mathrm{l}, 100 \mathrm{ng}$ of reverse-transcribed total RNA, $500 \mathrm{nM}$ of the forward and reverse primers, and $14 \mu \mathrm{l}$ of $2 \times$ SYBR green buffer (Roche). PCR amplification was initiated with a 10-min pre-incubation step at $95^{\circ} \mathrm{C}$, followed by 45 cycles of denaturation at $95^{\circ} \mathrm{C}$ for $10 \mathrm{~s}$, annealing at $58^{\circ} \mathrm{C}$ (iNOS) or $63^{\circ} \mathrm{C}$ ( $\beta$-actin) for $5 \mathrm{~s}$, and an elongation step at $72^{\circ} \mathrm{C}$ for $10 \mathrm{~s}$. The relative concentrations of the PCR products derived from the target gene (iNOS) were calculated using LightCycler System software. The results were expressed relative to the number of $\beta$-actin transcripts used as an internal control. All experiments were conducted in triplicate.

\section{Western blot analysis}

Cells were homogenized in $100 \mu$ of ice-cold lysis buffer (20 mM Hepes, pH 7.2, 1\% Triton X-100, 10\% glycerol, $1 \mathrm{mM}$ phenylmethylsulfonyl fluoride, 10 $\mu \mathrm{g} / \mathrm{ml}$ leupeptin and $10 \mu \mathrm{g} / \mathrm{ml}$ aprotinin). The homogenates, containing $20 \mu \mathrm{g}$ of protein, were separated via SDS-PAGE with $10 \%$ acrylamide resolving and $3 \%$ stacking gels, then transferred to nitrocellulose sheets in a Western blot apparatus (Bio-Rad, Hercules, CA). The nitrocellulose paper was blocked with $2 \% \mathrm{BSA}$, then incubated for $4 \mathrm{~h}$ with $1 \mu \mathrm{g} / \mathrm{ml}$ of primary antibodies for iNOS, $I_{\kappa} B \alpha, I_{\kappa} B \beta$, or p65 (Santa Cruz Biochemicals, Santa Cruz, CA). Horseradish peroxidase-conjugated IgG (Zymed, South San Francisco, CA) was employed as a secondary antibody. Protein expression levels were determined via analysis of the signals captured on nitrocellulose membranes, using a Chemi-doc image analyzer (Bio-Rad).

\section{Preparation of nuclear extracts}

Nuclear extracts were prepared as previously described (Park and Park, 2001). The cells were immediately washed twice, scraped into $1.5 \mathrm{ml}$ of ice-cold PBS ( $\mathrm{pH} 7.9)$, and pelleted at 12,000 $\times \mathrm{g}$ for $30 \mathrm{~s}$. The cell pellets were then suspended in ice-cold hypotonic lysis buffer (10 mM Hepes, 1.5 $\mathrm{mM} \mathrm{MgCl}, 0.2 \mathrm{mM} \mathrm{KCl}, 0.2 \mathrm{mM}$ phenylmethylsulfonylfluoride and $0.5 \mathrm{mM}$ dithiothreitol), vortexed for $10 \mathrm{~s}$ and then centrifuged for $5 \mathrm{~min}$ at $3,000 \mathrm{rpm}$. The packed cells were resuspended with ice-cold hypotonic lysis buffer in the presence of $50 \mu \mathrm{l}$ of $10 \%$ Nonidet P-40, then incubated for $25 \mathrm{~min}$ on ice. The nuclear fractions were precipitated via $15 \mathrm{~min}$ of centrifugation at $4,000 \mathrm{rpm}$. $I_{\kappa} B \alpha$ and $I_{\kappa} B \beta$ in the cytoplasmic fractions were analyzed via Western blotting. The pelleted nuclei were then resuspended in $50-100 \mu \mathrm{l}$ of low salt extraction buffer $(20 \mathrm{mM}$ Hepes, $\mathrm{pH} 7.9,1.5 \mathrm{mM} \mathrm{MgCl}_{2}, 25 \%$ glycerol, $20 \mathrm{mM}$ $\mathrm{KCl}, 0.2 \mathrm{mM}$ EDTA, $0.2 \mathrm{mM}$ phenylmethylsulfonylfluoride and $0.5 \mathrm{mM}$ dithiothreitol) and added to equal volumes of high salt extraction buffer $(20 \mathrm{mM}$ Hepes, $\mathrm{pH} 7.9,1.5 \mathrm{mM} \mathrm{MgCl}_{2}, 25 \%$ glycerol, $80 \mathrm{mM}$ $\mathrm{KCl}, 0.2 \mathrm{mM}$ EDTA, $0.2 \mathrm{mM}$ phenylmethylsulfonyl- 
fluoride and $0.5 \mathrm{mM}$ dithiothreitol) in a dropwise fashion, then incubated for 45 min under continuous shaking at $4^{\circ} \mathrm{C}$. The samples were centrifuged for 20 $\min$ at $12,000 \times g$. Aliquots of the nuclear extracts were stored at $-80^{\circ} \mathrm{C}$. Protein concentrations were determined by the Bradford method (Bradford, 1976).

\section{Electrophoretic mobility shift assay (EMSA)}

$N F-\kappa B$ activation was assayed via a gel mobility shift assay using nuclear extracts from the control and treated cells (Kim et al., 2005). As a probe for the gel retardation assay, an oligonucleotide harboring the $\kappa$-chain binding site $(\kappa \mathrm{B}, 5$ '-CCGGTTAACAGAGGGGGCTTTCCGAG-3') was synthesized. The two complementary strands were annealed and labeled with $\left[\alpha^{-32} \mathrm{P}\right] \mathrm{dCTP}$. Labeled oligonucleotides $(10,000 \mathrm{cpm}), 10 \mu \mathrm{g}$ of nuclear extracts, and binding buffer $(10 \mathrm{mM}$ Tris- $\mathrm{HCl}, \mathrm{pH} 7.6,500 \mathrm{mM} \mathrm{KCl}, 10 \mathrm{mM}$ EDTA, $50 \%$ glycerol, $100 \mathrm{ng}$ poly (dl.dC) and $1 \mathrm{mM}$ DTT) were incubated for $30 \mathrm{~min}$ at room temperature in a final volume of $20 \mu$ l. The reaction mixtures were analyzed via electrophoresis on $4 \%$ polyacrylamide gel in $0.5 \times$ Tris-borate buffer. The gels were dried and examined via autoradiography. Specific binding was controlled by competition with a 50 -fold excess of cold $\kappa B$ oligonucleotide.

\section{Isolation of islets}

Pancreatic islets were isolated from male SpragueDawley rats via collagenase digestion as previously described (Kim et al., 1994). After isolation, the islets were cultured overnight in RPMI-1640 (RPMI1640 containing $2 \mathrm{mM}$ L-glutamine, $10 \%$ heatinactivated FCS, $100 \mathrm{U} / \mathrm{ml}$ penicillin, and $100 \mu \mathrm{g} / \mathrm{ml}$ streptomycin) under an atmosphere of $95 \% \mathrm{O}_{2}$ and $5 \% \mathrm{CO}_{2}$ at $37^{\circ} \mathrm{C}$. Prior to each experiment, the islets were washed three times in RPMI-1640, counted, and cultured overnight.

\section{Insulin secretion assay}

The islets were cultured for $24 \mathrm{~h}$ with cytokines in the presence or absence of CRE. The islet were washed three times in Krebs-Ringer bicarbonate buffer $(25 \mathrm{mM}$ Hepes, $115 \mathrm{mM} \mathrm{NaCl}, 24 \mathrm{mM}$ $\mathrm{NaHCO}_{3}, 5 \mathrm{mM} \mathrm{KCl}, 1 \mathrm{mM} \mathrm{MgCl}, 2.5 \mathrm{mM} \mathrm{CaCl}_{2}$, and $0.1 \% \mathrm{BSA}, \mathrm{pH} 7.4$ ) containing $3 \mathrm{mM}$ D-glucose, and insulin secretion assays were conducted in the presence of either 5.5 or $20 \mathrm{mM} \mathrm{D-glucose.} \mathrm{The}$ insulin contents of the medium were determined via ELISA (Park et al., 1995).

\section{Statistical analysis}

Statistical analysis of the data was performed with ANOVA and Duncan's test. Differences with $P<$ 0.05 were considered statistically significant.

A

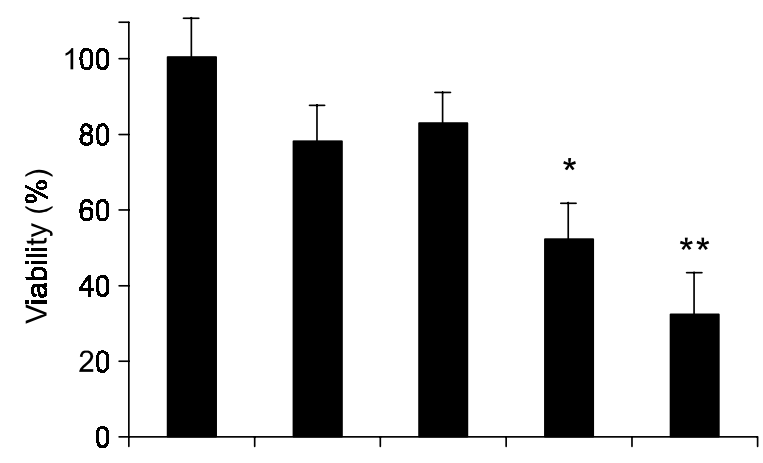

B

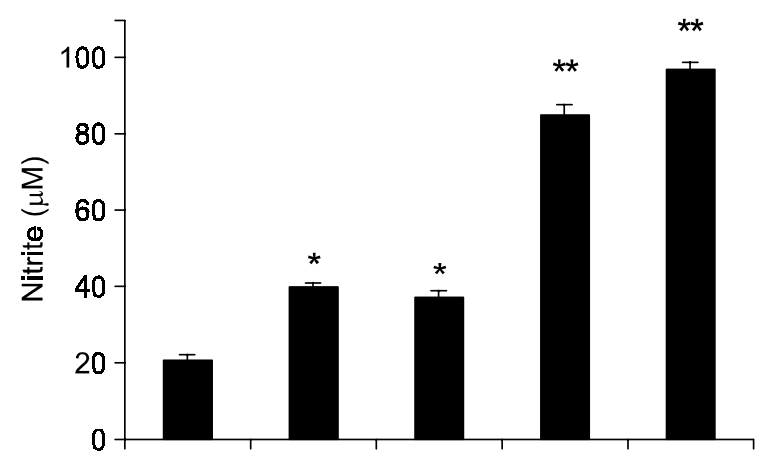

C

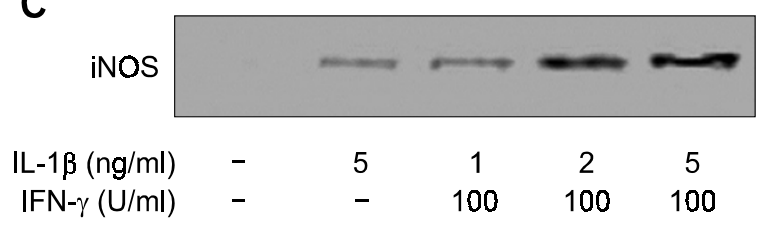

Figure 1. Cytokine-induced viability, NO production, and iNOS expression in RIN cells. (A) RIN cells $\left(1 \times 10^{5}\right)$ were incubated with IL-1 $\beta$ alone or combined with IFN- $\gamma$ as indicated. The percentage of cells viable after these treatments was determined via MTT colorimetric assay and calculated as the $A_{570}$ ratio of treated- and control cells (treated with $0.05 \%$ DMSO vehicle). (B) Cells $\left(4 \times 10^{5}\right)$ were treated for $48 \mathrm{~h}$ with the cytokines and the nitrite concentrations were assessed in the cell-free culture supernatants as a reflection of NO synthesis. The results of triplicate samples were expressed as the means \pm SEM. ${ }^{*} P<0.05,{ }^{* *} P<0.01$ vs. untreated control. (C) Cells $\left(5 \times 10^{6}\right)$ were incubated with cytokines and Western blot analysis for iNOS was conducted. 
A

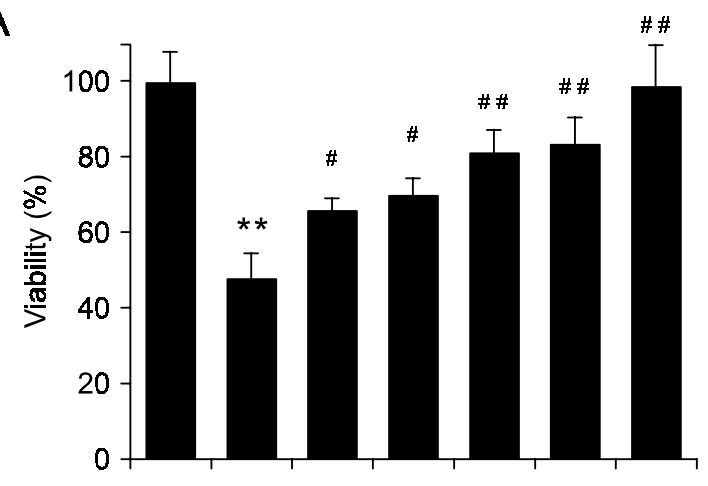

B
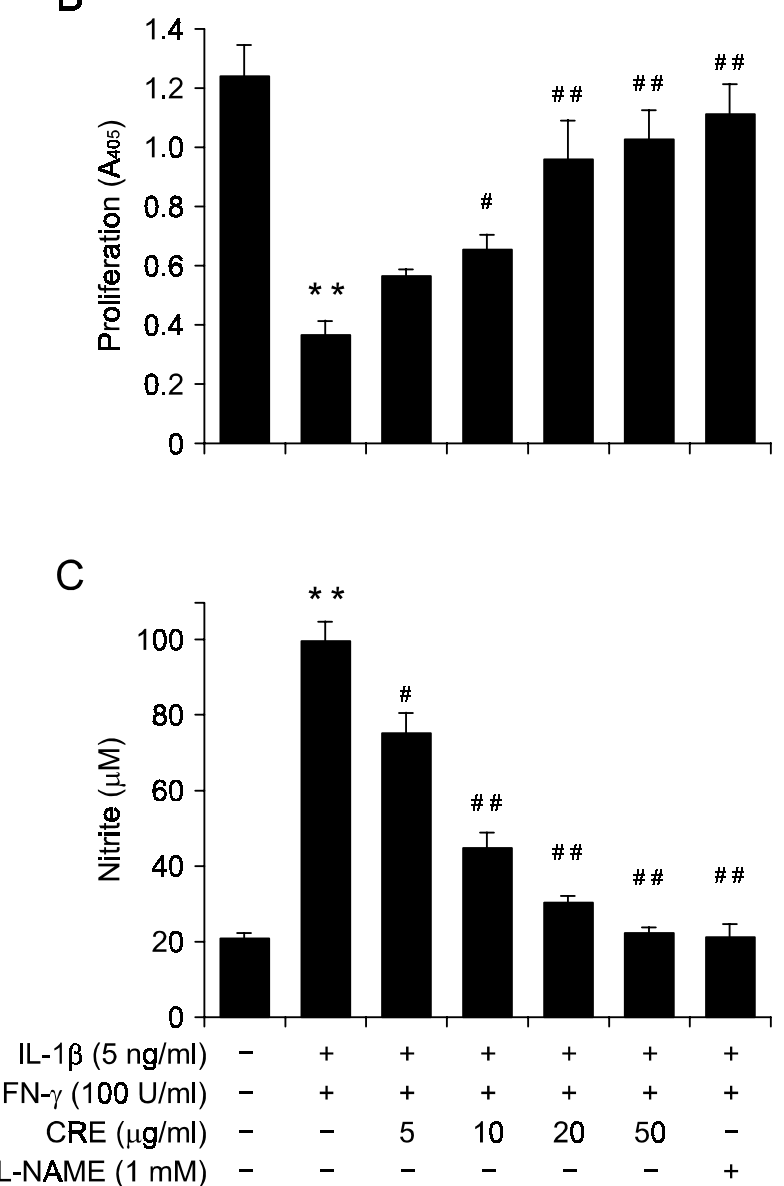

Figure 2. Prevention of cytokine-induced cell death by CRE. RIN cells $\left(1 \times 10^{5}\right)$ were incubated with cytokines in the presence or absence of CRE or L-NAME for $48 \mathrm{~h}$ as indicated. Cell viability (A), proliferation capacity $(B)$, and NO production $(C)$ were determined. Each value is expressed as the mean \pm SEM of four independent experiments. $P$ $<0.01$ vs. control; ${ }^{\#} P<0.05,{ }^{\#} P<0.01$ vs. IL- $1 \beta+$ IFN- $\gamma$.

\section{Results \\ Prevention of cytokine-induced viability reduction by CRE}

RIN cells from a rat pancreatic $\beta$-cell line were cultured to near confluence. A single treatment with $\mathrm{IL}-1 \beta(5 \mathrm{ng} / \mathrm{ml})$ induced a reduction in viability to $78.2 \pm 9.7 \%$, whereas the combination of IL-1 $\beta$ (5 $\mathrm{ng} / \mathrm{ml})$ and $\mathrm{IFN}-\gamma(100 \mathrm{U} / \mathrm{ml})$ induced a significant reduction in cell viability, of $32.6 \pm 10.8 \%$ (Figure $1 \mathrm{~A})$. By way of contrast, CRE increased the viability of IL-1 $\beta$ and IFN- $\gamma$-treated RIN cells in a concentration-dependent manner (Figure 2A). The protective effects of CRE on IL- $1 \beta$ and IFN- $\gamma$-induced cytotoxicity were confirmed further via the incorporation of BrdU into RIN cells. BrdU is a thymidine analogue that is incorporated into proliferating cells during DNA synthesis; thus, it is reflective of the proliferative potential of the cells. IL-1 $\beta$ and IFN- $\gamma$ reduced the level of BrdU incorporation, hence proliferation, at $48 \mathrm{~h}$ incubations to $29.5 \pm 3.2 \%$ of control levels (Figure 2B). Consistent with the data obtained in the MTT assay, CRE prevented the cytokine-mediated decrease in cell proliferation potential, coupled with an increase in its concentration (Figure 2B). CRE alone did not affect the viability, even at higher concentrations $(1 \mathrm{mg} / \mathrm{ml})$ (data not shown).

\section{Effect of CRE on IL-1 $\beta$ and IFN- $\gamma$-induced NO production by RIN cells}

It has been reported that the IL-1 $\beta$ and IFN- $\gamma$ mediated destruction of $\beta$-cells is induced by an increase in NO production (Eizirik et al., 1996; Flodstrom et al., 1996). The incubation of RIN cells with IL-1 $\beta$ and IFN- $\gamma$ for $48 \mathrm{~h}$ resulted in significant nitrite (a stable oxidized product of NO) production by these cells (Figure 1B). The addition of L-NAME, an iNOS inhibitor, completely prevented the IL-1 $\beta$ and IFN- $\gamma$-induced reduction in viability, as had been expected (Figure 2). The presence of CRE attenuated cytokine-mediated nitrite production, a result that was correlated well with its increased viability (Figure 2). In order to determine whether CRE inhibits NO production via the suppression of iNOS gene expression, changes in iNOS mRNA and protein levels were investigated via RT-PCR and Western blot analysis, respectively. Cells treated with IL-1 $\beta$ alone induced a slight increase in iNOS mRNA (Figure 1C, lane 2) and $130 \mathrm{kDa}$ iNOS protein expression (Figure 3, lane 2), whereas marked increases of iNOS mRNA and protein were observed in the cells treated with IL-1 $\beta$ and IFN- $\gamma$ (Figure 1C, lane 5 and Figure $3 \mathrm{~A}$ and $3 \mathrm{~B}$, lane 3 ). Cells pretreated with CRE at a concentration of 50 


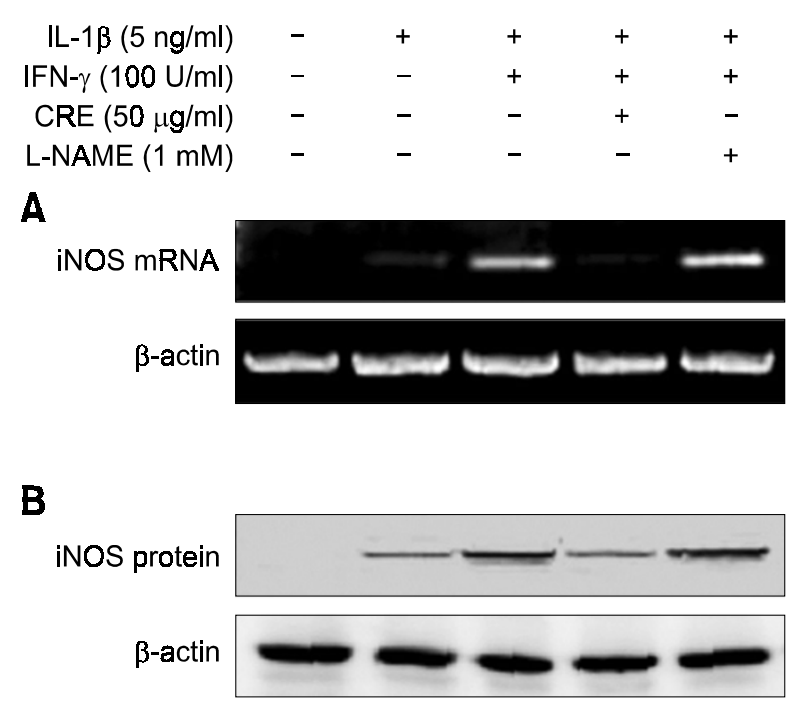

Figure 3. Inhibition of cytokine-induced iNOS expression by CRE. RIN cells $\left(5 \times 10^{6}\right)$ were incubated with IL-1 $\beta(5 \mathrm{ng} / \mathrm{ml})$ and/or IFN- $\gamma(100$ $\mathrm{U} / \mathrm{ml})$ in the presence or absence of CRE $(50 \mu \mathrm{g} / \mathrm{ml})$ or L-NAME (1 $\mathrm{mM}$ ) for $48 \mathrm{~h}$. RT-PCR (A) and Western blot analysis (B) for iNOS were conducted. A representative result is presented among at least three separate experiments with similar results.

$\mu \mathrm{g} / \mathrm{ml}$ showed suppressed iNOS expressions in both their mRNA and protein levels (Figure 3). These results show that IL-1 $\beta$ and IFN- $\gamma$-induced NO production were induced by iNOS expression in the RIN cells.

\section{Effect of CRE on IL-1 $\beta$ and IFN- $\gamma$-induced NF- $\kappa$ B activation}

$\mathrm{NF}-\mathrm{KB}$ has been implicated in the transcriptional regulation of cytokine-induced iNOS expression. Thus, we attempted to determine the effects of CRE on the cytokine-stimulated translocation of NF-kB from the cytoplasmic compartment to the nucleus in RIN cells. The IL- $1 \beta$ and IFN- $\gamma$-stimulated RIN cells resulted in increases in NF- $\kappa \mathrm{B}$ binding activity and p65 subunit levels within their nuclei (Figure 4A and $4 B$ ) and $I_{\kappa} B \alpha$ degradation in the cytosol (Figure 4B), as compared to unstimulated cells. I $B \beta$ was not affected by treatments with IL- $1 \beta$ and IFN- $\gamma$ (data not shown). IL-1 $\beta$ and IFN- $\gamma$-induced NF-kB activation and $I_{\kappa} B \alpha$ degradation were suppressed markedly by the addition of CRE, suggesting that CRE inhibits the expression of iNOS via the inhibition of NF-kB activation. The specificity of the DNA-protein interactions for $\mathrm{NF}-\kappa \mathrm{B}$ was demonstrated via competition assays using a 50 -fold excess of unlabeled oligonucleotides (Figure 4A, lane 4).

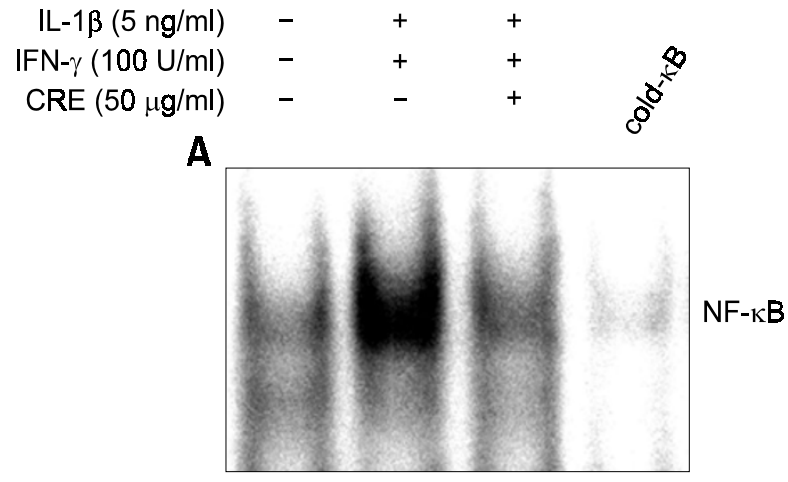

B

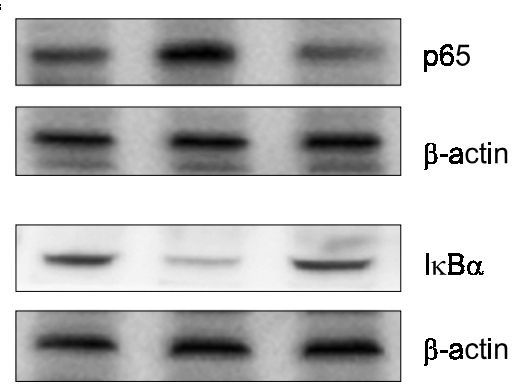

Figure 4. Inhibition of cytokine-stimulated translocation of $N F_{\kappa B}$ to the nucleus and $I \kappa B \alpha$ degradation by CRE. RIN cells $\left(5 \times 10^{6}\right)$ were treated with IL-1 $13(5 \mathrm{ng} / \mathrm{ml})$ and IFN- $\gamma(100 \mathrm{U} / \mathrm{ml})$ in the presence or absence of CRE $(50 \mu \mathrm{g} / \mathrm{ml})$. After $30 \mathrm{~min}$ of incubation, NF- $\mathrm{kB}$ translocation was analyzed by EMSA (A), and p65 expression and $1 \kappa B \alpha$ degradation $(B)$ were evaluated by Western blotting.

Reduction of NO production and preservation of glucose-stimulated insulin secretion by CRE in the presence of IL-1 $\beta$ and IFN- $\gamma$

We further assayed the preventive effects of CRE on cytokine-induced NO production, iNOS expression, and GSIS using rat pancreatic islets isolated from male Sprague-Dawley rats to support the physiological importance of the results observed in the cell line studies (Figure 5). $24 \mathrm{~h}$ of incubation of the rat islets with IL-1 $\beta$ and IFN- $\gamma$ resulted in 3.4-fold and 7.6-fold increases in nitrite production and iNOS mRNA expression, respectively (Figure 5A). However, islets treated with $\mathrm{IL}-1 \beta$ and IFN- $\gamma$ in the presence of L-NAME produced control levels of nitrite. The incubation of islets with IL-1 $\beta$ and IFN- $\gamma$ for $24 \mathrm{~h}$ also resulted in marked iNOS protein expression (Figure $5 \mathrm{C}$ ) and a significant reduction of GSIS from $10.2 \pm 0.6 \mathrm{ng} / \mathrm{ml}$ to $4.8 \pm 1.6 \mathrm{ng} / \mathrm{ml}$ (Figure 5D). Pretreatment with CRE blocked the effects of IL-1 $\beta$ and IFN- $\gamma$ on nitrite production and iNOS expression, and restored insulin secretion responses to glucose in a concentration-dependent manner. CRE alone had no effect on insulin-secre- 
A

A

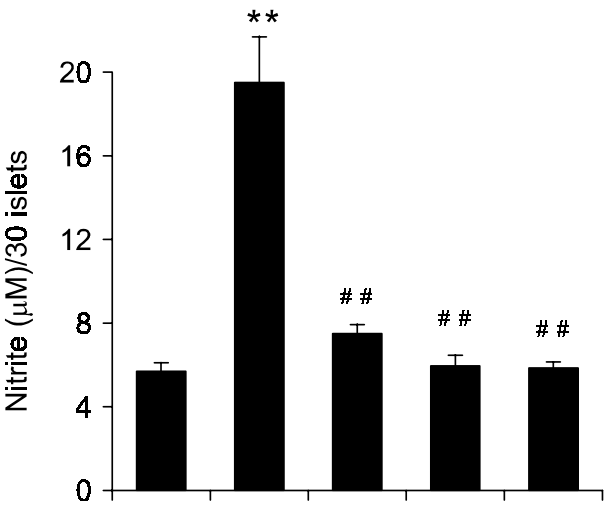

B

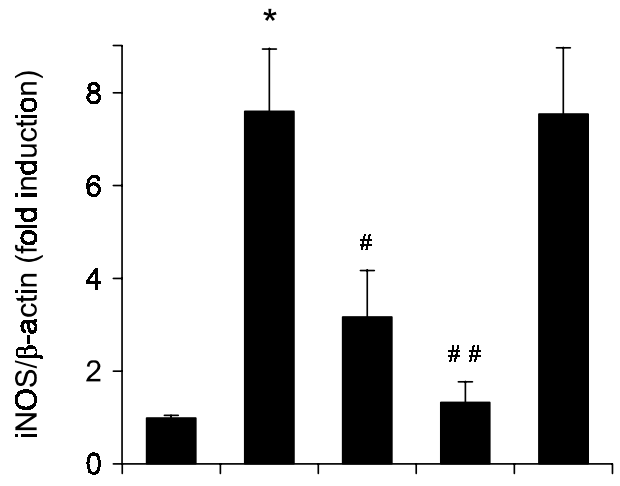

$\mathrm{IL}-1 \beta(5 \mathrm{ng} / \mathrm{ml})$

IFN- $\gamma(100 \mathrm{U} / \mathrm{ml})$

CRE $(\mu \mathrm{g} / \mathrm{ml})$

L-NAME (1 mM)
C

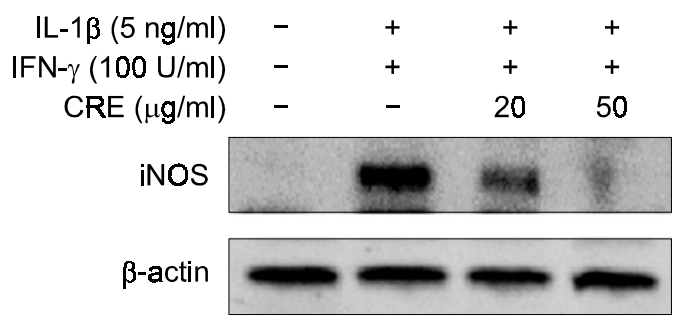

D

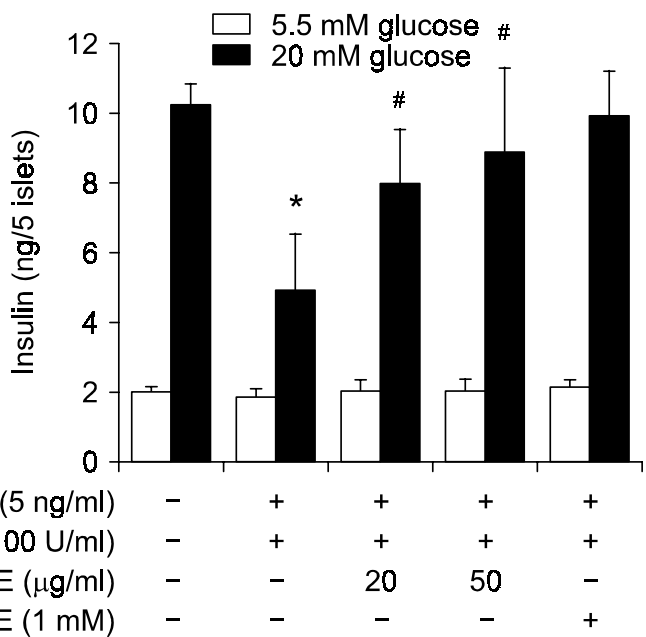

Figure 5. Effects of CRE on IL-1 $\beta$ and IFN- $\gamma$-induced NO production, iNOS expression, and glucose-stimulated insulin secretion. Rat islets (30 islets/500 $\mu \mathrm{l}$ ) were treated with cytokines in the presence or absence of CRE or L-NAME for $24 \mathrm{~h}$ as indicated. After the incubation period, NO production (A) and iNOS mRNA (B) and protein (C) expressions were assessed. (D) For GSIS, five islets were utilized and assayed as described in the Materials and Methods section. Results of triplicate samples were expressed as the mean $\pm S E M$. ${ }^{*} P<0.05$, ${ }^{* *} P<0.01$ vs. untreated control; ${ }^{\#}<0.05,{ }^{\# \prime} P<0.01$ vs. IL- $1 \beta+$ IFN- $\gamma$.

ting responses to glucose (data not shown).

\section{Discussion}

In this study, we have evaluated the preventative effects of CRE on IL- $1 \beta$ and IFN- $\gamma$-induced reductions of viability in $\beta$-cells. Rat insulinoma cells, pretreated with CRE, proved resistant to cytokineinduced cytotoxicity, as assessed by MTT and BrdU assays. The protective actions of CRE on cellular metabolism are associated with an inability of $\beta$-cells to express iNOS or generate NO in response to cytokines. The activation of the transcriptional regulator, NF-kB , was required for cytokine-induced iNOS expression by $\beta$-cells. We observed that CRE prevented cytokine-induced NF- $\mathrm{KB}$ nuclear translocation via the inhibition of $I_{\kappa} B \alpha$ degradation. These findings show that CRE provides functional protection against the damaging effects of cytokines by preventing the expression of iNOS.

Cytokines, as humoral mediators of inflammation, cause the destruction of pancreatic $\beta$-cells of various species, including rats and humans (Eizirik et al., 1996; Mandrup-Poulsen, 1996). It has been previously shown that, whereas IL-1 $\beta$ is a sufficient stimulus for the induction of iNOS mRNA expression and NO production in RIN cells, a combination of $\mathrm{IL}-1 \beta$ and IFN- $\gamma$ is required for the induction of NO formation by human islets (Cetkovic-Cvrlje and Eizirik, 1994; Eizirik et al., 1996; Heitmeier et al., 1997; Lortz et al., 2000). The increased toxicity of the cytokine combination compared with that of IL-1 $\beta$ alone (Figure 1 ) is attributable to a significantly higher rate of iNOS mRNA and protein expression (Figure 3 ) and subsequent NO production (Figure 
1B). Data obtained in other cell types suggest that putative sites for the action of IFN- $\gamma$ include the stabilization of iNOS mRNA (Vodovotz et al., 1993), the potentiation of IL-1 $\beta$-induced NF-KB activation (Amoah-Apraku et al., 1995), and the induction of other nuclear transcription factors, including the interferon regulatory factor-1 (Flodstrom and Eizirik, 1997).

$\mathrm{NF}-\kappa \mathrm{B}$ governs both proinflammatory and antiapoptotic responses according to the mode of insults in $\beta$-cells. NF- $\mathrm{B} B$ regulates the expressions of multiple proinflammatory genes that contribute to islet destruction, including Fas, iNOS, and cyclooxygenase-2 (Cetkovic-Cvrlje and Eizirik, 1994; Sorli et al., 1998; Darville and Eizirik, 2001). In addition, the promoters of other proinflammatory genes induced in $\beta$-cells, including chemokines and adhesion mol-

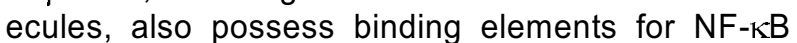
(May and Ghosh, 1998). The importance of NF-kB in $\beta$-cell damage is underscored by the fact that the inhibition of $\mathrm{NF}-\kappa \mathrm{B}$ activation or translocation prevents IL- $1 \beta$ and IFN- $\gamma$-induced $\beta$-cell dysfunction and death, in both in vitro and in vivo models (Kwon et al., 1998; Giannoukakis et al., 2000; Heimberg et al., 2001; Eldor et al., 2006). By way of contrast, aside from its proinflammatory functions, there is a wealth of data on the defensive and protective functions of $N F-\kappa B$. NF- $k B$ limited tissue damage in a ceruleaninduced acute pancreatitis model, whereas the blockage of NF- $\mathrm{KB}$ activation exerted an adverse effect by causing increased tissue damage by increasing apoptosis (Steinle et al., 1999). NF- $\mathrm{KB}$ regulates apoptosis via its ability to control the expression of multiple antiapoptotic genes, including the inhibitor of apoptosis protein (IAP) and A20 (Karin and Lin, 2002; Liuwantara et al., 2006). Blockade of $N F-\kappa B$ via the use of an $I_{\kappa} B \alpha$ superrepressor also sensitized $\beta$-cells to TNF- $\alpha$-mediated apoptosis (Chang et al., 2003). Thus, it remains to

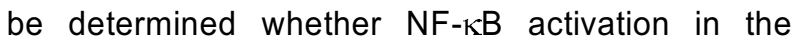
pancreas is protective or detrimental.

Previous reports have provided evidence that chemical inhibitors of NO generation protected insulin-secreting cells against cytokine-mediated toxicity, but with variable efficacy, depending on the species and the combination of the cytokines (Darville and Eizirik, 1998; Rabinovitch and SuarezPinzon, 1998). We have already reported on the protective effects of herbs and dietary supplements against cytokine- or cytotoxin-induced $\beta$-cell damage via the suppression of iNOS expression (Park and Park, 2001; Kwon et al., 2003a, b, 2005, 2006; Kim et al., 2007). Many other groups have also attempted to save $\beta$-cells from those insults by re-

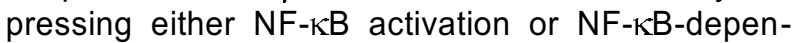
dent iNOS expression (Scarim et al., 1998; Ho and
Bray, 1999; Ho et al., 1999; Evans et al., 2002). With regard to this feature, the repression of NF-kB or its downstream iNOS expression are important targets for the protection of $\beta$-cells against a variety of diabetogenic agents. Indeed, we recently determined the protective effects of CRE against S-nitroso-N-acetylpenicillamine-induced apoptotic cell death in RIN cells (Kwon et al., 2005). With the current study, we further demonstrated the importance of NO generation in $\beta$-cell damage, which was prevented by treatment with L-NAME, an iNOS inhibitor. Taken together, our results indicate that NO is an indispensable component of the cytokine- or cytotoxin-induced toxicity of $\beta$-cells, and the protective effect of CRE against IL- $1 \beta$ and IFN- $\gamma$-mediated killing is attributable to the inhibition of NO generation.

In addition, data in the relevant literature indicate that cytokine-induced NF-KB activation and iNOS induction can be suppressed in islets by antioxidants including pyrrolidine dithiocarbamate (Kwon et al., 1995). Moreover, NF-KB is a redox-sensitive transcription factor, as indicated by the fact that NF-kB activation can be induced by $\mathrm{H}_{2} \mathrm{O}_{2}$ or, conversely, $\mathrm{NF}-\kappa \mathrm{B}$ nuclear translocation is blocked by antioxidants including pyrrolidine dithiocarbamate (Schreck et al., 1991; Ferran et al., 1995). Interestingly, several studies have addressed the protective potential of antioxidants in the islets via the overexpression of free radical-scavenging enzymes (Kubisch et al., 1997; Benhamou et al., 1998; Hohmeier et al., 1998). The overexpression of manganese-superoxide dismutase (MnSOD) in an engineered $\beta$-cell induced selective protection against cytokineinduced cytotoxicity, in addition to a reduction of cytokine-induced NO generation (Hohmeier et al., 1998). Berberine, a major alkaloidal component of Coptidis rhizoma has been reported to exert antidiabetic effects in a variety of animal models of diabetes (Leng et al., 2004; Lee et al., 2006; Tang et al., 2006). One possible antidiabetic mechanism involves its ability to scavenge oxygen free radicals. Berberine-treated animals showed increases in superoxide dismutase and glutathione peroxidase activities, as compared with control rats (Tang et al., 2006). Therefore, we are unable to dismiss the possibility that oxygen free radicals may be involved in our system, and that the protective effects of CRE occur via the reduced generation of oxygen free radicals. The potential for CRE to interfere at the oxidative step of $N F-\kappa B$ activation is currently under examination.

In summary, we have demonstrated the profound inhibitory effect of CRE against cytokine-induced viability reduction in $\beta$-cells, using an insulinoma cell line and isolated pancreatic islets. CRE rescued 
$\beta$-cells from cytokine-induced toxicity and completely restored function. No other reports have yet been published regarding the relation of CRE with the prevention of $\beta$-cell damage against cytokine toxicity. The results of this study will provide valuable information not only into the mechanisms underlying autoimmune $\beta$-cell destruction, but also into the development of drugs designed to combat Type 1 diabetes.

\section{Acknowledgement}

This work was supported by the Ministry of Science and Technology (MOST)/Korea Science and Engineering Foundation (KOSEF) through the Vestibulocochlear Research Center (VCRC) at Wonkwang University (R13-2002-05500000-0) and by a grant of the Oriental Medicine R\&D Project, Ministry of Health and Welfare, Republic of Korea (02-PJ9-PG3-20500-0009).

\section{References}

Amoah-Apraku B, Chandler LJ, Harrison JK, Tang SS, Ingelfinger JR, Guzman NJ. NF-kB and transcriptional control of renal epithelial-inducible nitric oxide synthase. Kidney Int 1995;48:674-82

Baeuerle PA, Henkel T. Function and activation of NF-kB in the immune system. Annu Rev Immunol 1994;12:141-79

Baldwin AS Jr. The NF-kB and $I_{\kappa} B$ proteins: new discoveries and insights. Annu Rev Immunol 1996;14:649-83

Benhamou PY, Moriscot C, Richard MJ, Beatrix O, Badet L, Pattou F, Kerr-Conte J, Chroboczek J, Lemarchand P, Halimi $\mathrm{S}$. Adenovirus-mediated catalase gene transfer reduces oxidant stress in human, porcine and rat pancreatic islets. Diabetologia 1998;41:1093-100

Bradford MM. A rapid and sensitive method for the quantitation of microgram quantities of protein utilizing the principle of protein-dye binding. Anal Biochem 1976;72:248-54

Cetkovic-Cvrlje M, Eizirik DL. TNF- $\alpha$ and IFN- $\gamma$ potentiate the deleterious effects of IL- $1 \beta$ on mouse pancreatic islets mainly via generation of nitric oxide. Cytokine 1994;6:399-406

Chan CP, But PP, Ho JW. Induction of $r c l$, a novel growthrelated gene by Coptidis rhizoma in rat H4IIE cells. Life Sci 2002;70:1691-9

Chang I, Kim S, Kim JY, Cho N, Kim YH, Kim HS, Lee MK, Kim $\mathrm{KW}$, Lee MS. Nuclear factor $\kappa \mathrm{B}$ protects pancreatic $\beta$-cells from tumor necrosis factor- $\alpha$-mediated apoptosis. Diabetes 2003;52:1169-75

Corbett JA, Wang JL, Sweetland MA, Lancaster JR Jr, McDaniel ML. Interleukin $1 \beta$ induces the formation of nitric oxide by $\beta$-cells purified from rodent islets of Langerhans. Evidence for the $\beta$-cell as a source and site of action of nitric oxide. J Clin Invest 1992;90:2384-91

Corbett JA, McDaniel ML. Intraislet release of interleukin 1 inhibits $\beta$ cell function by inducing $\beta$ cell expression of inducible nitric oxide synthase. J Exp Med 1995;181:559-68

Cunningham JM, Green IC. Cytokines, nitric oxide and insulin secreting cells. Growth Regul 1994;4:173-80

Darville MI, Eizirik DL. Regulation by cytokines of the inducible nitric oxide synthase promoter in insulin-producing cells. Diabetologia 1998;41:1101-8

Darville MI, Eizirik DL. Cytokine induction of Fas gene expression in insulin-producing cells requires the transcription factors NF-KB and C/EBP. Diabetes 2001;50:1741-8

Eizirik DL, Flodstrom M, Karlsen AE, Welsh N. The harmony of the spheres: inducible nitric oxide synthase and related genes in pancreatic beta cells. Diabetologia 1996;39:875-90

Eldor R, Yeffet A, Baum K, Doviner V, Amar D, Ben-Neriah Y, Christofori G, Peled A, Carel JC, Boitard C, Klein T, Serup P, Eizirik DL, Melloul D. Conditional and specific NF-kB blockade protects pancreatic beta cells from diabetogenic agents. Proc Natl Acad Sci USA 2006;103:5072-7

Evans JL, Goldfine ID, Maddux BA, Grodsky GM. Oxidative stress and stress-activated signaling pathways: a unifying hypothesis of type 2 diabetes. Endocr Rev 2002;23:599-622

Ferran C, Millan MT, Csizmadia V, Cooper JT, Brostjan C, Bach $\mathrm{FH}$, Winkler $\mathrm{H}$. Inhibition of NF-kB by pyrrolidine dithiocarbamate blocks endothelial cell activation. Biochem Biophys Res Commun 1995;214:212-23

Flodstrom M, Welsh N, Eizirik DL. Cytokines activate the nuclear factor $\kappa B(N F-\kappa B)$ and induce nitric oxide production in human pancreatic islets. FEBS Lett 1996;385:4-6

Flodstrom M, Eizirik DL. Interferon- $\gamma$-induced interferon regulatory factor-1 (IRF-1) expression in rodent and human islet cells precedes nitric oxide production. Endocrinology 1997; 138:2747-53

Giannoukakis N, Rudert WA, Trucco M, Robbins PD. Protection of human islets from the effects of interleukin- $1 \beta$ by adenoviral gene transfer of an $1 \kappa B$ repressor. J Biol Chem 2000;275:36509-13

Green LC, Wagner DA, Glogowski J, Skipper PL, Wishnok JS, Tannenbaum SR. Analysis of nitrate, nitrite, and $\left[{ }^{15} \mathrm{~N}\right]$ nitrate in biological fluids. Anal Biochem 1982;126:131-8

Heimberg $\mathrm{H}$, Heremans $\mathrm{Y}$, Jobin $\mathrm{C}$, Leemans $\mathrm{R}$, Cardozo AK, Darville M, Eizirik DL. Inhibition of cytokine-induced NF-kB activation by adenovirus-mediated expression of a NF-kB super-repressor prevents $\beta$-cell apoptosis. Diabetes 2001;50: 2219-24

Heitmeier MR, Scarim AL, Corbett JA. Interferon- $\gamma$ increases the sensitivity of islets of Langerhans for inducible nitric-oxide synthase expression induced by interleukin 1 . J Biol Chem 1997;272:13697-704

Ho E, Bray TM. Antioxidants, NF-kB activation, and diabetogenesis. Proc Soc Exp Biol Med 1999;222:205-13

Ho E, Chen G, Bray TM. Supplementation of N-acetylcysteine inhibits NF-kB activation and protects against alloxan-induced diabetes in CD-1 mice. Faseb J 1999;13:1845-54 
Hohmeier HE, Thigpen A, Tran VV, Davis R, Newgard CB. Stable expression of manganese superoxide dismutase (MnSOD) in insulinoma cells prevents IL-1 $\beta$-induced cytotoxicity and reduces nitric oxide production. J Clin Invest 1998;101:1811-20

lizuka N, Miyamoto K, Hazama S, Yoshino S, Yoshimura K, Okita K, Fukumoto T, Yamamoto S, Tangoku A, Oka M. Anticachectic effects of Coptidis rhizoma, an anti-inflammatory herb, on esophageal cancer cells that produce interleukin 6. Cancer Lett 2000a;158:35-41

lizuka N, Miyamoto K, Okita K, Tangoku A, Hayashi H, Yosino S, Abe T, Morioka T, Hazama S, Oka M. Inhibitory effect of Coptidis Rhizoma and berberine on the proliferation of human esophageal cancer cell lines. Cancer Lett 2000b;148:19-25

lizuka N, Hazama S, Yoshimura K, Yoshino S, Tangoku A, Miyamoto K, Okita K, Oka M. Anticachectic effects of the natural herb Coptidis rhizoma and berberine on mice bearing colon 26/clone 20 adenocarcinoma. Int J Cancer 2002;99: 286-91

Jorns A, Gunther A, Hedrich HJ, Wedekind D, Tiedge M, Lenzen S. Immune cell infiltration, cytokine expression, and $\beta$-cell apoptosis during the development of type 1 diabetes in the spontaneously diabetic LEW.1AR1/Ztm-iddm rat. Diabetes 2005;54:2041-52

Kanazawa Y, Komeda K, Sato S, Mori S, Akanuma K, Takaku F. Non-obese-diabetic mice: immune mechanisms of pancreatic $\beta$-cell destruction. Diabetologia 1984;27 Suppl:113-5

Karin M, Lin A. NF- $\mathrm{kB}$ at the crossroads of life and death. Nat Immunol 2002;3:221-7

Kim EK, Kwon KB, Lee JH, Park BH, Park JW, Lee HG, Jhee EC, Yang JY. Inhibition of cytokine-mediated nitric oxide synthase expression in rat insulinoma cells by scoparone. Biol Pharm Bull 2007;30:242-6

Kim HR, Rho HW, Park BH, Park JW, Kim JS, Kim UH, Chung MY. Role of $\mathrm{Ca}^{2+}$ in alloxan-induced pancreatic $\beta$-cell damage. Biochim Biophys Acta 1994;1227:87-91

Kim SK, Kim JH, Kim BS, Chung HY, Lee YY, Park CS, Lee YS, Lee YH, Chung IY. Identification and functional characterization of an alternative spice variant within the fourth exon of human nanog. Exp Mol Med 2005;37:601-7

Kubisch HM, Wang J, Bray TM, Phillips JP. Targeted overexpression of $\mathrm{Cu} / \mathrm{Zn}$ superoxide dismutase protects pancreatic $\beta$-cells against oxidative stress. Diabetes 1997;46: 1563-6

Kwon G, Corbett JA, Rodi CP, Sullivan P, McDaniel ML. Interleukin-1 $\beta$-induced nitric oxide synthase expression by rat pancreatic $\beta$-cells: evidence for the involvement of nuclear factor $\kappa B$ in the signaling mechanism. Endocrinology 1995; 136:4790-5

Kwon G, Corbett JA, Hauser S, Hill JR, Turk J, McDaniel ML. Evidence for involvement of the proteasome complex (26S) and $\mathrm{NF} K \mathrm{~B}$ in IL-1 $\beta$-induced nitric oxide and prostaglandin production by rat islets and RINm5F cells. Diabetes 1998;47:583-91

Kwon KB, Kim JH, Lee YR, Lee HY, Jeong YJ, Rho HW, Ryu
DG, Park JW, Park BH. Amomum xanthoides extract prevents cytokine-induced cell death of RINm5F cells through the inhibition of nitric oxide formation. Life Sci 2003a;73:181-91

Kwon KB, Ryu DG, Shin MK, Shin BC, Hwang WJ, Lee YR, Park JW, Park BH. Fructus Benincasae Recens extract prevents cytokine-induced nitric oxide formation and cytotoxicity of RINm5F cells. Immunopharmacol Immunotoxicol 2003b;25:615-25

Kwon KB, Kim EK, Lim JG, Shin BC, Han SC, Song BK, Kim KS, Seo EA, Ryu DG. Protective effect of Coptidis Rhizoma on S-nitroso-N-acetylpenicillamine (SNAP)-induced apoptosis and necrosis in pancreatic RINm5F cells. Life Sci 2005; 76:917-29

Kwon KB, Kim EK, Jeong ES, Lee YH, Lee YR, Park JW, Ryu DG, Park BH. Cortex cinnamomi extract prevents streptozotocin- and cytokine-induced $\beta$-cell damage by inhibiting NF-kB. World J Gastroenterol 2006;12:4331-7

Lee YS, Kim WS, Kim KH, Yoon MJ, Cho HJ, Shen Y, Ye JM, Lee CH, Oh WK, Kim CT, Hohnen-Behrens C, Gosby A, Kraegen EW, James DE, Kim JB. Berberine, a natural plant product, activates AMP-activated protein kinase with beneficial metabolic effects in diabetic and insulin-resistant states. Diabetes 2006;55:2256-64

Leng SH, Lu FE, Xu LJ. Therapeutic effects of berberine in impaired glucose tolerance rats and its influence on insulin secretion. Acta Pharmacol Sin 2004;25:496-502

Liuwantara D, Elliot M, Smith MW, Yam AO, Walters SN, Marino E, McShea A, Grey ST. Nuclear factor- $\kappa B$ regulates $\beta$-cell death: a critical role for A20 in beta-cell protection. Diabetes 2006;55:2491-501

Lortz S, Tiedge M, Nachtwey T, Karlsen AE, Nerup J, Lenzen $S$. Protection of insulin-producing RINm5F cells against cytokine-mediated toxicity through overexpression of antioxidant enzymes. Diabetes 2000;49:1123-30

Mandrup-Poulsen T. The role of interleukin-1 in the pathogenesis of IDDM. Diabetologia 1996;39:1005-29

May MJ, Ghosh S. Signal transduction through NF-kB. Immunol Today 1998;19:80-8

Moncada S, Palmer RM, Higgs EA. Nitric oxide: physiology, pathophysiology, and pharmacology. Pharmacol Rev 1991; 43:109-42

Nossal GJ, Herold KC, Goodnow CC. Autoimmune tolerance and type 1 (insulin-dependent) diabetes mellitus. Diabetologia 1992;35 Suppl 2:S49-59

Park BH, Rho HW, Park JW, Cho CG, Kim JS, Chung HT, Kim $H R$. Protective mechanism of glucose against alloxaninduced pancreatic $\beta$-cell damage. Biochem Biophys Res Commun 1995;210:1-6

Park BH, Park JW. The protective effect of Amomum xanthoides extract against alloxan-induced diabetes through the suppression of NF-kB activation. Exp Mol Med 2001;33: 64-8

Rabinovitch A, Suarez-Pinzon WL. Cytokines and their roles in pancreatic islet $\beta$-cell destruction and insulin-dependent diabetes mellitus. Biochem Pharmacol 1998;55:1139-49 
Scarim AL, Heitmeier MR, Corbett JA. Heat shock inhibits cytokine-induced nitric oxide synthase expression by rat and human islets. Endocrinology 1998;139:5050-7

Schreck R, Rieber P, Baeuerle PA. Reactive oxygen intermediates as apparently widely used messengers in the activation of the NF- $\mathrm{kB}$ transcription factor and HIV-1. Embo J 1991;10:2247-58

Sorli CH, Zhang HJ, Armstrong MB, Rajotte RV, Maclouf J, Robertson RP. Basal expression of cyclooxygenase-2 and nuclear factor-interleukin 6 are dominant and coordinately regulated by interleukin 1 in the pancreatic islet. Proc Natl Acad Sci USA 1998;95:1788-93

Southern C, Schulster D, Green IC. Inhibition of insulin secretion by interleukin- $1 \beta$ and tumour necrosis factor- $\alpha$ via an L-arginine-dependent nitric oxide generating mechanism. FEBS Lett 1990;276:42-4

Steinle AU, Weidenbach H, Wagner M, Adler G, Schmid RM. NF-kB/Rel activation in cerulein pancreatitis. Gastroentero- logy 1999;116:420-30

Tang LQ, Wei W, Chen LM, Liu S. Effects of berberine on diabetes induced by alloxan and a high-fat/high-cholesterol diet in rats. J Ethnopharmacol 2006;108:109-15

Vodovotz Y, Bogdan C, Paik J, Xie QW, Nathan C. Mechanisms of suppression of macrophage nitric oxide release by transforming growth factor $\beta$. J Exp Med 1993; 178:605-13

Welsh N, Eizirik DL, Bendtzen K, Sandler S. Interleukin$1 \beta$-induced nitric oxide production in isolated rat pancreatic islets requires gene transcription and may lead to inhibition of the Krebs cycle enzyme aconitase. Endocrinology 1991;129: 3167-73

Zhang SU, Park KW, Oh S, Cho HJ, Cho HJ, Park JS, Cho YS, Koo BK, Chae IH, Choi DJ, Kim HS, Lee MM. NF-kB decoy potentiates the effects of radiation on vascular smooth muscle cells by enhancing apoptosis. Exp Mol Med 2005;37:18-26 